STUDIA UKRAINICA POSNANIENSIA, vol. II: 2014, pp. 103-111.

ISBN 978-83-936654-5-7. ISSN 2300-4754.

\title{
МІФОЛОГІЧНА КНИГА ЖИТТЯ. ТВОРЧІ ПОШУКИ БОГДАНА ІГОРЯ АНТОНИЧА І БРУНО ШУЛЬЦА
}

\author{
ІРИНА СКРИПНИК
}

Інститут літератури імені Т.Г. Шевченка НАНУ, Київ - Україна

\section{MITOLOGICZNA KSIĘGA ŻYCIA. TWÓRCZE POSZUKIWANIA BOHDANA IHORA ANTONYCZA I BRUNO SZULCA}

\author{
IRYNA SKRYPNYK \\ Instytut Literatury im. T. Szewczenki Narodowej Akademii Nauk Ukrainy, Kijów - Ukraina \\ STRESZCZENIE. W artykule omówione zostały najważniejsze cechy idiostylów Bohdana Ihora An- \\ tonycza oraz Brunona Schulza, które ujawniają strategie tworzenia mitu w twórczości obu pisa- \\ rzy. Analizie poddane zostały zarówno teksty literackie, jak i korespondencja autorów, a także \\ publicystyka oraz szkice krytyczne.
}

\section{MYTHOLOGICAL BOOK OF LIFE. CREATIVE SEARCHES OF BOHDAN IGOR ANTONYCH AND BRUNO SCHULTZ}

\author{
IRYNA SKRYPNYK
}

National Academy of Sciences of Ukraine Shevchenko Institute of Literature, Kyiv - Ukraine ABSTRACT. The article deals with the main biographical and textual writing features of B.-I. Antonych and B. Schultz that reveal the initial points of myth in works of both writers. The texts, correspondences between the writers, their journalism and critical essays are analyzed.

$\mathrm{T}$

вори Богдана Ігоря Антонича та Бруно Шульца ми розглядаємо крізь призму міфологічного хронотопу та триєдиного космічного цииклу, що включає в себе космогонічний пласт, еротизм як розквіт та есхатологію як занепад, смерть. У цій студії безпосередньо не будемо торкатись зазначених ланок, а закцентуємо увагу на своєрідних витоках, основах моделювання міфологічного циклу від біографічних фактів до власне текстів, які в той чи інший спосіб виступали рецепцією світосприйняття авторів, оскільки нам важливо прослідкувати своєрідний момент зародження такого виду локальної міфосвідомості та визначити підгрунтя зазначених звернень. Саме тому у статті представлений порівняльний аналіз позатекстової реальності (факти біографiї, епістолярій, спогади, публіцистика, малярська спадщина) й зображення цих фактів у творах.

Міфологічна циклічність часу в творчості Антонича і Шульца легко накладається структурно на філософію й культурологічні погляди Освальда 
Шпенглера та Арнольда Джозефа Тойнбі. Перший з них у своїй фундаментальній праці Присмерк Свропи (1918) протиставляє культуру цивілізації як розквіт смерті й аналізує міфологічні типи грецької та римської культур. Другий - спроектовує життя культур на життя рослини (gabitus), що проходить три стадії у своєму розвитку: народження, розквіт і смерть (Дослідження icmopiï, 1934-1961). Смерть філософ вбачає в цивілізації як у точці розпаду культури й іiі асиміляції або розкладанні на багато малих культур, що проходять ці ж рівні заново.

Передумовою творення текстів Б.І Антонича та Б. Шульца були різноманітні біографічні та рецепиійні міфологеми, які ми спробуємо окреслити, щоб дійти до своєрідних витоків, першопочатків міфотворчості обох авторів.

Послуговуватимемось епістолярієм письменників, статтями та нарисами, спогадами про них, самими текстами, що цікавлять нас як кінцевий результат міфологічних рецепцій митців, збірними портретними образами, які усталились в літературознавстві та літературних колуарах.

Розглянемо кілька біографічних штрихів, що, на нашу думку, стали вихідними пунктами творчості Б.І. Антонича та Б. Шульца.

Першим важливим пунктом виступає провінційність як вибір, як своєрідна офіра власній творчості. Обрання маргінальності як можливості бачити світ збоку, відсторонено, крізь призму занурення в міф, у лоно природи, в праслово, очищену від нальоту XX століття сутність речей.

Із листування Б. Шульца бачимо, що в нього була можливість переїхати жити та працювати до Варшави, позбавитися ненависної та виснажливої праці в школі, але страх покинути Дрогобич, свою мекку, місце та предмет своєї міфологізації, побороти всі внутрішні фобії, примусити притушити в собі андрогінність, відстороненість від всього плотського були сильнішими за особисте людське щастя.

Саме через небажання та боязнь зміни топосу й звичної, вже оміфотвореної атмосфери розірвалися стосунки з нареченою Ю. Шелінською. Очевидно, якщо б Юзефина погодилась, щоб ці зносини тривали лише на папері, тобто в формі листування, яке для Шульца було формою життя, то це цілком влаштовувало б митця. Тому тут до провінційності як вибору слушно додати самотність як вибір, самотність заради мистецтва, заради спроможності сублімувати всі життєві, побутові „недо-” у творчість.

Б.І. Антонич - за походженням лемко, а після закінчення Львівського університету залишився жити й працювати у Львові. Статус „селюка” авторові довго намагались привити як критики, так і просто поціновувачі його творів, наївно вбачаючи в його перших збірках Привітання життя (1931) та Три перстені (1934) лише рустикальні мотиви (С. Маланюк). Таке сприйняття було, очевидно, пов'язане й з мовою Б.І. Антонича, лемківським діалектом, що до загального образу додавав поетові ще одного ярлика - поляка. Ірина Вільде пригадує: „Антонич, будучи вже в університеті, говорив якось дуже «дивно» по-українськи, так, що ми, дівчата, навіть подекуди (неписані дороги 
твої, доле!) бокували зразу від нього, вважаючи його за поляка, що робиться «приємним» до нас, українок"1. Тому письменник завжди носив на собі кліше дивака-провінціала, лемка, що спустився з гір, а Львів як беззаперечна провінція став пристанищем для поета, що зробив його ареною апокаліптичних міфічних подій, наділив ознаками міфологічного топосу.

Важливим $є$ те, що висловлена нами думка про провінційність як вибір стосується лише реального, життєвого простору обох митців. Оскільки якраз фактичний маргінальний, бічний, а не центральний топос став основою для централізації текстуального часопростору, винесення, виштовхання всіх первнів міфу, всіх біблійних архетипів у центр власного текстовсесвіту, тому що у їхніх творах міф сягає глобальних візій, концентраційними колами вводить все живе в міф як первісну, безкінечну, бо змінну саму в собі оповідь.

Якщо розглядати листування та есе, статті, дискусійні звернення як спосіб спілкування, то Б. Шульц більш схильний до епістолярію, що можна характеризувати як бажання спілкуватися віддалено й приватно, лише у двосторонньому зв'язку, діалогічно, що, по суті, $є$ боротьбою між реальною самотністю й мнимим, ілюзорним наповненням свого життя людьми, кодуванням приватної міфології, що і лягла в основу творчості.

Ретроспекція в міф - у випадку прозаїка - у власне дитинство, що синтезує в собі дитинство історії, праісторію чи метаісторію, вимагала лише манери оповіді, нарації, тому і в художніх текстах ми маємо оповідь від першої особи, концептуальну оповідну структуру, що підсилювала бажання бути почутим, підсилювала міф самотності та відчуття старіння часу, його зужитості.

Щодо Антонича, горизонтальне заглиблення в корінь суті, в міф як матрицю первісної образної оповіді, а отже, первісного біологічного та ментального знання, тотальне охоплення у текстуальному міфі всього живого виражають більшу відкритість, екстравертність міфопростору:

$$
\begin{aligned}
& \text { У дно, у суть, у корінь речі, в лоно, } \\
& \text { у надро слова і у надро сонця! } \\
& \text { В екстазнім шалі, в час коли найтонша, } \\
& \text { роздерти вглиб свідомості запону, } \\
& \text { аж зсунеться із нас, мов зайва шкура }
\end{aligned}
$$

Відкритість потверджується і біографією поета. Листування Антонича також частково збереглося, але воно вдивовижу штрихове й поверхневе, не відображає настроїв, життєвих позицій, відкриває читачеві ділову літературну практику автора. Проте публіцистичне надбання письменника $€$ чи не найголовніше після художньої спадщини (що вже є ознакою відкритості, адже апелює не до певної особи, що маємо у випадку листування, а якщо не до мас, то принаймні, до більшого кола читачів).

${ }^{1}$ Цит. за: Д. М а к о г о н, Образи і порівняння в поезї Богдана-Ігоря Антонича, [в:] „Світ молоді” 1935, ч. 5, с. 13.

${ }^{2}$ Б.І. А н т о н и ч, Велика гармонія, Київ 2003, с. 174. 
Автор відстоював свої власні письменницькі позиції у статтях, що вилились у форму своєрідної полеміки в Національному мистецттві (1933), Hamхненні та ремеслі (1938), Примітивній європеїзації (1934), Становищі поета (1935), де намагався донести до галицької аудиторії, що

сучасна література не дала й не може дати синтези. Розпорошеність, роздрібленість, розкладництво, атомізування може діяти лише в тому самому напрямі, себто також на спосіб розкладницький. Розклад $є$ першим ступенем до занепаду. Сучасне мистецтво має всі прикмети занепадництва, а його вплив $є$ і може бути тільки негативний. Новітня хвора душа видала й може видати хвору творчість ${ }^{3}$.

Втратити синкретизм, тобто первісну єдність 3 природою, $з$ генетичною пам'яттю - втратити себе. Тому подальшу думку в Кризі сучасної літератури (1932) автор виводить 3 того, що єдиний вихід зі „сліпої вулиці ” - досвід минулого, шлях ,,ad fondes”.

Безперечно, мова не йде про суто національні джерела. Б. Шульца й Б.І. Антонича в зображанні міфохронотопу об'єднує глобалістичність охоплення, мікрокосмос розростається до макрокосмосу й шляхом приватної, звуженої міфології, шляхом локального топосу Лемківщини (у Привітанні життя (1931) та особливо - в Трьох перстениях (1934)), Львова (главах Зеленої Свангелії (1938) та Книги Лева (1936), Ротаџіях (1938)), Дрогобича (у повісті Весна (1935), оповіданнях Цинамонові крамниці (1934), Трактат про манекени (1934), Книга (1935) тощо) і до крайньої степені міфологізованого Трускавия, якому Б. Шульц надав статусу “вічного міста”, міста останньої пристані, де відбувається сакральний перехід одного міфологічного циклу - в інший, де міняються місцями чаші клепсидри.

У Антонича статус міфологічного міста-пристанища набуває дещо звужених особливостей - „дім за третьою зорею”, мікромісто, топос в собі:

Мій дім за третьою зорею. В ньому жде мене кохана.

Заходить ніч увита в клоччя сну, що від проміння тонше, зір цвяхами прибита до землі, де плещуть аж до рана останні солов'ї, що миють крила у сходячім сонці. В зорі рожевих палях карта смутку затремтить і в'яне. Хвилину дай п’яніти! Впитись дай собою до нестями... ${ }^{4}$.

Чи:

Мабуть, мій дім не тут. Мабуть, аж за зорею.

Поки я тут, інстинктом чую це: співаю - тож існую 5 .

Саме тут набуває значення так званий „космогонічний шов”, який можна спровадити до компаративного аналізу текстів Б.І. Антонича та Б. Шульца і розглядати як пункт переходу одного міфологічного циклу в інший. Тобто

${ }^{3}$ Б.І. А н т о н и ч, Повне зібрання творів, Львів 2009, с. 574.

${ }^{4}$ Б.І. А н т о н и ч, Велика гармонія, зазнач. праця, с. 190.

${ }^{5}$ Там само, с. 102. 
точка крайньої межі катастрофізму й смерть заради народження в космогонії, чим, по суті, виступають Санаторій niд клепсидрою (1935) Шульца, катастрофічні фрагменти Весни (1935) та Ночі Великого Сезону (1934), а в Б.І. Антонича натомість прослідковується у вічному природному колообігу, - як переходять спіралеподібно, геноподібно чаші клепсидри, так само матерія як ознака життя, переходить 3 одного стану в інший, з однієї форми в іншу, змінюючи лише образ, наповненість:

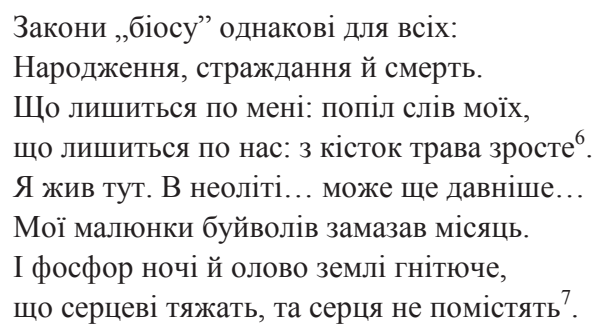

Якщо структурно порівнювати наповненість міфохронотопу Б. Шульца та Б.І. Антонича, то рецепція поета більш „м’якша”, андрогінна, об'єктивна, дещо піднесена. Б. І. Антонич у Трьох перстенях та ліричних інтермецяо Зеленої Євангелї й Книги Лева підносить „зелене життя” в лоні Матері Природи, де навіть кров тече ,зелена”. Ліричне „я” тут часто виступає в формі тварини чи рослини: „Нас двоє - два кошлаті й сплетені кущі”, ,„Стіл обростає буйним листям, і разом з кріслом я вже кущ. / 3 черемх читаю - 3 книг столистих - рослинну мудрість вічних пущ"9. Цикл моновіршів 3 зелених думок одного лиса (2003) (не внесений до жодної збірки) корелює наскрізні мотиви ліричних інтермецо - єдина істина - рости, „потопати в буянні”, щоб потім перейти на іншу спіраль життя.

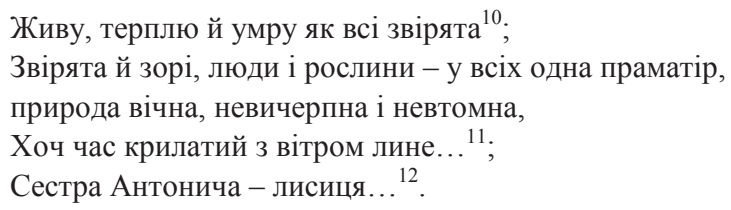

У Б. Шульца домінує маскулінна, хтива, згрубіла рецепція міфохронотопу, патологічність текстового ландшафту (що бачимо в Б.І. Антонича в Pomaцุiяx, 1938). Варто лише звернути увагу на описи профанного топосу в оповіданні Серпень (1934):

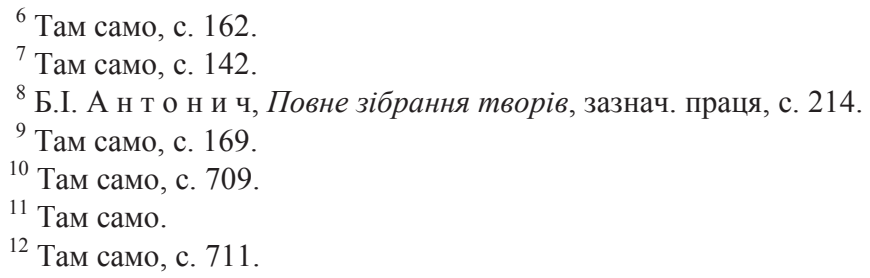


Було щось трагічне в тій неохайній та непоміркованій плодючості, було горе креатури, яка боролася на грані небуття і смерти, був якийсь героїзм жіночости, яка тріумфувала урожайністю навіть над каліцтвом природи, над неспроможністю мужчини ${ }^{13}$.

Варто згадати й про малярські твори Б. Шульца, зокрема альбом офортів Ідолопоклонна книга (1920-1922), де повсякчас зображені образи жінок-домінанток, поклоніння туфельці як показовому символу жінки. Звідси маскулінність в текстах, надання батькові як одному із головних героїв більшості текстів образу Деміурга, називання світу, де „ще не було матері”, блаженним часом: „То було дуже давно. Матері тоді ще не було. Я проводив дні на одинці з батьком, у нашому покої, великому тоді, як світ"14. Таку відвертість варто вважати компенсуванням психологічних проблем сприймання жінки, які переслідували Шульца ще з малечку.

Б. Шульц практично не виходив з депресій, це видно з багатьох листів, зокрема до Тадеуша і Зоф’ї Брезів, до Зенона Вишневського, Дебори Фогель, Анни Плоцкер та інших. У листі до Станіслава Віткевича Б. Шульц пише: „Самотність є тим чинником, який доводить реальність до бродіння, до осадження гранул фігур і барв"15, тобто самотність доводить реальність, її сприйняття до вичавлення своєрідної есенції, згущеної міфологічної пам'яті. Це лише потверджує зазначену вище думку про офіру всіх життєвих принад мистецтву.

Весь світ Б. Шульца, як і світ Б.І. Антонича, складається з антиномій (про це влучно зазначає Л. Стефановська, 2006). Так вже в листі до 3. Вишневського Шульцу приходить й інше розуміння самотності:

Я не мав розради з тої самотності і позбувся старої та глибоко в мені вкоріненої ілюзії, що я створений для самотності. Може, колись я був, а нині зяє на мене порожнеча і мертвотність краєвиду, я не можу вже сам поживитися при столі Господа Бога ${ }^{16}$.

3 цього приводу С. Фіцовський зауважує:

По суті, ми маємо в тих листах справу з різновидом інцидентальної, часткової сповіді письменника, який наче у дзеркалі приглядається до себе у чужих творах, щоб побачити там власне обличчя ${ }^{17}$.

На жаль, війна забрала більшість листів письменника, але, і з того, що дійшло до нас, можна зробити висновки, що авторові було значно легше спілкуватися в епістолярний спосіб. Не випадково Цинамонові крамниці постали в листах до „проникливої та вдячної читачки” Дебори Фогель (польська письменниця, філософ, літературний критик), а своєрідна „гра в міф” почалась із

${ }^{13}$ Б. Ш у л ь ц, Цинамонові крамниці, перекл. 3 польської А. Шкраб’юка, Львів 2005, c. 26 .

14 Там само, с. 111

${ }^{15}$ Б. Ш у л ь ц, Книга листів, перекл. 3 польської А. Павлишина, Київ 2012, с. 90.

16 Там само, с. 76

${ }^{17}$ Є. Ф і ц о в с ь к и й, Регіони великої єресі та околиці, перекл. з польської А. Павлишина, Київ 2010, с. 213. 
листування зі Владиславом Ріфом (практично невідомий польський письменник початку XX ст., який помер у дуже молодому віці від сухот легенів й всі рукописи його текстів були знищені під час дезінфекції приміщення), що став, за словами Б. Шульца, тогочасним „спільником для новаторських починань",

Слушною щодо герметизації власного „я” в міфі як такому є ще одна ознака Б. Шульца та Б.І. Антонича - часте автокоментування, навіть коли мовиться про інших, тобто як вони не намагались, але все-таки не могли виходити за рамки накреслених міфологічних, закритих в собі первнів. Щодо Антонича, то, наприклад, читаємо це в рецензії на тексти Д. Лоуренса:

Суворість і полум'яна замисловість. Містичні наголоси й полум'яне захоплення життям. Християнський зрив до височин і поганський культ дочасного. Гіркий песимізм і діоніська життєрадісність. Похмурий пуританізм і похвала первісних сил природи ${ }^{18}$.

Про таку особливість у Б. Шульца читаємо у Фіцовського:

В опублікованій у Сигналах рецензії на вірші Юліуша Віта ми раз-у-раз знаходимо подібні рефлекси власної Шульцівської аури, моделювання об'єктів оцінки на власний образ і подобу ${ }^{19}$.

Іншим, на наш погляд, важливим елементом біографії $є$ те, що обоє письменників дійшли у своїй творчості від космогонії до стадії катастрофізму, есхатології, тому їхню фізичну смерть (дивний відхід від запалення легень та своєрідне згасання молодого Б.І. Антонича, „нагла куля” за кілька годин перед гаданою втечею з Дрогобича від есесівця у Б. Шульца) можна трактувати як метафізичний перехід, як завершення однієї ланки, циклу міфу.

Ставлення до міфу і до часу Б.І. Антонича та Б.Шульца знаходимо як у текстах, так і в листах (коли мова йде про Б. Шульца), статтях. Програмним щодо цього питання $є$ есе прозаїка Мітологізація дійсності (1936). Основою міфу як такого, оповіді про творення світу є слово як первісне синкретичне містилище смислів і матриць розуміння:

Слово у звичайному сьогоднішньому значенні $є$ лише фрагментом, рудиментом якоїсь давньої всеосяжної, інтегральної мітології... У поета деякою мірою слово опам'ятовується відповідно до свого суттєвого сенсу; воно розквітає та розвивається спонтанно згідно із власними законами, віднаходить свою цілісність. Тому будь-яка поезія є мітологізуванням: вона прагне відтворення мітів про світ. Мітологізація світу не є закінченою ${ }^{20}$

У цей же час Б.І. Антонич в Національному мистец̧тві зазначає:

${ }^{18}$ Б.І. А н т о н и ч, Повне зібрання творів, зазнач. праця, с. 604.

${ }^{19}$ Є. Ф і ц о в с ь к и й, зазнач. праця, с. 206.

${ }^{20}$ Б. Ш у л ь ц, Літературно-критичні нариси, перекл. 3 польської В. Маньок, Київ 2012, c. 20. 
Мистецтво не відтворює дійсности, ані ії не перетворює, як хочуть другі, а лише створює окрему дійсність... мистецтво це окрема дійсність, яка викликує у нас переживання, потрібні для нашої психіки, а котрих не може дати нам реальна дійсність ${ }^{21}$.

Спільним первнем для Б. Шульца й Б.І. Антонича виступає занурення в дитинство як праісторію, в дитинство як сакралізований час, 3 якого бере початок цикл як такий. Б.І. Антонич часто ототожнює ліричне „,я” з рослиною чи твариною (профанною чи сакральною), що $є$ яскравою ознакою біологічного „дитинства світу” (,Антонич теж звіря сумне і кучеряве”, „нас двоє - два кошлаті й сплетені кущі”, „Антонич був хрущем”). Таке ототожнення та, зрештою, своєрідна нівеляція звичного, буденного hото надає образам поета особливої двоякої природи - з одного боку - ліричне ,я” як зооморфне чи фітоморфне, а з іншого - сама природа набуває особливостей hото, відбувається тотальне уособлення. М. Ільницький з цього приводу підкреслює:

Необхідною передумовою такої абсолютної природи можуть бути спогади дитинства, де першопочаток власного „я” є першопочатком світу взагалі. Тоді спогади переростають у казку, творять міт 22 .

Спогади-спалахи дитячих напівяв, бесонних ночей у розгляданні зоряного неба наскрізь пронизують поетову збірку Три перстені (тому що в наступних збірках автор уже „констатує” утверджене міфологічне сприйняття, віддзеркалення прадавніх культур):

$$
\begin{aligned}
& \text { П'яніючи отруйним чадом } \\
& \text { ночей сріблистих та гірких, } \\
& \text { дивлюся в місяця свічадо } \\
& \text { крізь шибу, повну світляних, } \\
& \text { холодних, синіх і тремких } \\
& \text { далеких відблисків світів, } \\
& \text { що, кинуті у тьму, горять } \\
& \text { самітні, горді, золоті, } \\
& \text { немов знаків санскритських ряд, } \\
& \text { які прадавнім сном дзвенять } 23 .
\end{aligned}
$$

Б. Шульц витоки своєї писемної творчості, в якій тематично описано історію родини автора, що ширше розуміється як історія роду людського, біблійні оповіді про Якова та Йосипа, пов’язував із своєрідною реконструкцією дитячих спогадів. У листі до С. Віткаци знаходимо рядки:

Так само, як люди в давнину виводили своїх предків 3 міфологічних подружжів 3 богами, так я вчинив спробу установити для себе якесь міфічне покоління антенатів, фіктивної родини, з якої я виводжу мій справжній рід ${ }^{24}$.

${ }^{21}$ Б.І. А н т о н и ч, Повне зібрання творів, зазнач. праця, с. 612.

${ }^{22}$ М. І л ь н и ц ь к и й, Від „Дочасного світла” до „Сурм останнього дня”, [в:] Богдан Ігор Антонич. Повне зібрання творів, Львів 2009, с. 12.

${ }^{23}$ Б.І. А н т о н и ч, Велика гармонія, зазнач. праця, с. 108.

${ }^{24}$ Цит. за: Є. Ф і ц о в с ь к и й, зазнач. праця, с. 65. 
Причиною втікання в дитинство була одна чи не найважливіша боязнь у житті письменника - безсилля перед часом, перед його скороминущістю:

Однією з головних нав'язливих ідей у житті Шульца був страх перед захланним часом, перед його обмеженою місткістю. Тому в його творчості час $\epsilon$ таким розлогим, ладним умістити в себе все, що захоче мати в ньому свою частку. Звідси - ушляхетнене запліднення буденного сьогодення минулим, добою міфу ${ }^{25}$.

Усі елементи творчості письменників у пригадуванні коду слова, коду регенерації первісної матерії, які в поєднанні й створюють ту іншу дійсність справжнього мистецтва, продовжують незакінчену міфологізацію світу, про яку говорять митці. Л. Стефановська, помітивши спільні риси між письменниками, наголошує:

Ця вражаюча паралель тим цікавіша, що хоча Шульц з Антоничем були сучасниками та географічними „сусідами” (Львів і Дрогобич), але, наскільки це можливо встановити, не знали творчости один одного. Очевидно, тут варто говорити не про взаємовпливи, а про Zeitgeist цього періоду та цієї території - співзвучність найважливіших мистецьких ідей, адже, як відомо, пошуки Праслова для Антонича, так само, як і для Шульца - справа фундаментальна ${ }^{26}$.

Мистецтво для обох авторів, - чи то словесне, чи то малярське, - період повернення до „втраченого раю”, до первісної недистильованої дійсності, реконструкція міфологічної книги життя. Не випадково багато творів письменників озаглавлені концептом „книга”, „трактат”, „глава” як частина книги чи твору - Зелена Євангелія - священна книга Природи, Книга Лева - книга міфологічного топосу есхатологічного міста у Б.І. Антонича; Книга, Книга ро$\partial y$ - оповідь про містичну рухому книгу життя, що відкриває знання всього, як й ім'я Бога, Трактат про Манекени (1934) - оповідь про патологічне покоління напівлюдей, напівтварин як поріддя есхатологічного віку в Б. Шульца.

Штрихово ми окреслили основні пункти витоків творення міфологічного хронотопу в текстах Б. Шульца та Б.І. Антонича. Безперечно, важливою ознакою „втікання” в міф стала „нездорова” атмосфера міжвоєнного періоду, коли лишень стихли гармати Першої світової, а в повітрі вже було чути порохом Другої світової війни. Саме тому кожен з них намагався надати сенс світові, який в реальному житті був тісний для глобалістичного первісного мислення поета-візіонера, в якому не було місця для звироднілого, антигуманного часу. Спільний топос та глибинне, автохтонне відчуття первісності дали змогу Б.І. Антоничу та Б. Шульцу не завжди однаковими шляхами дійти до спільної матриці - міфу, тричленної, замкненої у своїй природній довершеності моделі будови Всесвіту.

\footnotetext{
${ }^{25}$ Там само, с. 39.

${ }^{26}$ Л. С т е ф а н о в с ь к а, Антонич. Антиномії, Київ 2006, с. 172.
} 